\title{
Pengaruh Persentase Serat Sabut Pinang (Areca Catechu L. Fiber) dan Foam Agent terhadap Sifat Fisik dan Mekanik Papan Beton Ringan
}

\author{
Firda Yulia Citra*, Alimin Mahyudin \\ Jurusan Fisika FMIPA Universitas Andalas Kampus Unand, Limau Manis, Padang, 25163 \\ *Firdayc95@gmail.com
}

\begin{abstract}
ABSTRAK
Telah dilakukan penelitian tentang pengaruh persentase serat sabut pinang dan foam agent terhadap sifat fisik dan mekanik papan beton ringan. Penelitian ini menggunakan metode hand lay-up dengan memvariasikan persentase serat sabut pinang yaitu $0 \% ; 0,2 \% ; 0,4 \% ; 0,6 \%$ dan $0,8 \%$. Sifat fisik dan mekanik yang diujikan meliputi daya serap air, densitas, kuat tekan dan kuat lentur. Pengujian kuat tekan dan kuat lentur menggunakan universal testing machine (UTM). Hasil menunjukkan nilai daya serap air terendah diperoleh pada papan dengan persentase serat $0,8 \%$ yaitu $14,69 \%$, sedangkan densitas terendah diperoleh pada persentase serat $0,6 \%$ sebesar $1,42 \mathrm{~g} / \mathrm{cm}^{3}$. Nilai kuat lentur tertinggi diperoleh pada $0,4 \%$ serat yaitu $37,5 \mathrm{kgf} / \mathrm{cm}^{2}$. Kuat tekan tertinggi diperoleh pada pesentase serat $0,2 \%$ yaitu $54,87 \mathrm{kgf} / \mathrm{cm}^{2}$. Papan beton ringan serat sabut pinang dan foam agent memiliki sifat fisik lebih tinggi dibandingkan papan GRC.

Kata kunci: foam agent, hand lay-up, papan GRC serat sabut pinang.
\end{abstract}

\section{ABSTRACT}

The influence of Areca catechu L. fiber percentage and foam agent on the physical and mechanical properties of lightweight concrete boar has been conducted. The research using the hand lay-up method with variation of fiber $0 \% ; 0.2 \% ; 0.4 \% ; 0.6 \%$ and $0.8 \%$. The physical and mechanical properties such as water absorption, the density, compressive strength and flexural strength were determined. Flexural and compressive test are performed using Universal Testing Machine (UTM). The result show that board with $0.8 \%$ fiber have the lowest water absorption that is $14.69 \%$. The board with $0.6 \%$ fiber have the lowest density that is $1.42 \mathrm{~g} / \mathrm{cm}^{3}$.The highest flexural strength of $0.4 \%$ fiber that is $37.5 \mathrm{kgf} / \mathrm{cm}^{2}$, the highest compressive strength of $0.2 \%$ fiber that is $54.87 \mathrm{kgf} / \mathrm{cm}^{2}$. The physical properties of light concrete board with Areca catechu L. fiber and foam agent higher than GRC board.

Keywords: foam agent, hand lay-up, GRC board, Areca catechu L. fiber

\section{PENDAHULUAN}

Beton adalah material konstruksi yang saat ini sudah sangat umum digunakan. Berbagai bangunan sudah menggunakan material dari beton, pentingnya peranan beton menuntut suatu kualitas beton yang memadai. Keunggulan beton sebagai bahan konstruksi antara lain mempunyai kuat tekan yang tinggi, dapat mengikuti bentuk bangunan secara bebas, tahan terhadap api dan biaya perawatan yang relatif murah. Tetapi beton juga mempunyai beberapa kelemahan, yaitu lemah terhadap kuat tarik, mengembang dan menyusut bila terjadi perubahan suhu, sulit kedap air secara sempurna, dan bersifat getas (Tjokrodimuljo, 1996).

Penambahan serat pada beton dimaksudkan untuk memperbaiki kelemahan sifat yang dimiliki oleh beton yaitu memiliki kuat tarik yang rendah. Dalam penelitian ini serat yang akan digunakan adalah serat pinang. Pada serat pinang terdapat kadar selulosa dan hemiselulosa yang apabila ditambahkan pada campuran semen dan pasir pembentuk beton, senyawa ini akan terserap pada permukaan partikel dan memberikan tambahan kekuatan ikat antar partikel akibat sifat adhesi dan dispersinya, serta menghambat difusi air dalam material akibat sifat hidrofobnya. Dengan demikian dapat dihasilkan beton yang lebih kuat dan relatif tidak tembus air, yang dapat dipakai sebagai bahan konstruksi (Gargulak, 2001).

Penelitian menggunakan serat pinang telah dilakukan oleh Olanda dan Alimin (2013) dengan variasi persentase serat yang digunakan adalah $0 \% ; 0,2 \% ; 0,4 \% ; 0,6 \% ; 0,8 \%$ dan $1,2 \%$ terhadap massa adonan serat, semen, gipsum dan air. Dari hasil pengujian didapatkan nilai kuat tekan optimum pada papan dengan persentase serat 0,6\% yaitu sebesar $108,08 \mathrm{kgf} / \mathrm{cm}^{2}$, sedangkan nilai kuat lentur optimum diperoleh pada papan dengan persentase serat $0,6 \%$ yaitu sebesar $30,33 \mathrm{kgf} / \mathrm{cm}^{2}$. Daya serap air optimum diperoleh pada persentase serat $1,2 \%$ yakni sebesar $16,52 \%$, sedangkan densitas optimum diperoleh pada persentase serat $0,8 \%$ yaitu sebesar $1,139 \mathrm{~g} / \mathrm{cm}^{3}$. 
Beton ringan pada dasarnya sama dengan beton biasa, hal yang membedakan yaitu beton ringan tidak menggunakan agregat kasar. Sebagai bahan pengisinya biasanya pasir halus (lolos ayakan 50 mesh). Untuk membuat beton menjadi ringan dapat dilakukan dengan cara foaming mixture yaitu memberi busa dalam pasta beton (Nurrakhman dkk, 2014).

Penelitian dengan menggunakan foam agent telah dilakukan oleh Murtono (2015), dalam penelitiannya variasi foam agent yang ditambahkan pada komposisi campuran pasta beton adalah $0 \mathrm{~L} / \mathrm{m}^{3} ; 0,6 \mathrm{~L} / \mathrm{m}^{3} ; 0,8 \mathrm{~L} / \mathrm{m}^{3} ;$ dan $1,0 \mathrm{~L} / \mathrm{m}^{3}$ dari volume beton sebelum pencampuran. Dari hasil penelitiannya Dari kuat tekan tertinggi dicapai beton dengan kandungan foam agent $0,6 \mathrm{~L} / \mathrm{m}^{3}$ sebesar 4,02 MPa, kuat lentur balok beton dengan kandungan foam agent $0,6 \mathrm{~L} / \mathrm{m}^{3}$ sebesar $0,738 \mathrm{MPa}$. Murtono menyimpulkan bahwa semakin banyak penambahan busa foam agent membuat kuat lentur semakin rendah.

Berdasarkan penelitian sebelumnya, maka akan dilakukan penelitian tentang pengaruh persentase serat sabut pinang dan foam agent terhadap sifat fisik dan mekanik papan beton ringan, sehingga hasil dari penelitian ini diharapkan bisa mendapatkan material yang ringan dengan kekuatan tinggi.

\section{METODE}

Bahan yang digunakan dalam penelitian ini adalah serat pinang (Areca catechu L fiber) berfungsi sebagai penguat ikatan matriks yang panjangnya $1 \mathrm{~cm}$ dengan variasi serat $0 \% ; 0,2 \%$; $0,4 \%$ dan $0,8 \%$ terhadap volume cetakan, sedangkan bahan matriksnya adalah semen, pasir, foam agent dan air. Komposisi adonan terdiri dari penguat (serat) dan matriks yang dibuat dengan komposisi semen : pasir yaitu $1: 2$ dan semen : air berdasarkan FAS 0,4.

Papan beton ringan yang dibuat berukuran $5 \mathrm{~cm} \times 5 \mathrm{~cm} \times 1 \mathrm{~cm}$ untuk pengujian daya serap air, densitas, kuat tekan, sedangkan pengujian kuat lentur dibuat berukuran $20 \mathrm{~cm} \times 5 \mathrm{~cm}$ $\times 1 \mathrm{~cm}$. Pembuatan papan beton ringan menggunakan metode hand lay up dengan komposit serat yaitu pembentukan lapisan laminat dan satu lapisan penguat (serat) yang diletakkan ditengah lapisan laminat. Jumlah lapisan ada tiga, yaitu lapisan atas dan bawah untuk campuran pasta beton dengan foam agent dan lapisan tengah untuk serat pinang.

Sebelum membuat adonan pasta beton dan foam agent, semua bahan ditimbang dulu dengan perbandingan bahan yang telah ditentukan menggunakan timbangan digital. Pembuatan adonan dengan cara dicampur dan diaduk secara merata menggunakan sendok semen, setelah merata dicetak sesuai cetakan yang terbuat dari seng berukuran $5 \mathrm{~cm} \times 5 \mathrm{~cm} \times 1 \mathrm{~cm}$ dan $20 \mathrm{~cm}$ $\times 5 \mathrm{~cm} \times 1 \mathrm{~cm}$. Papan beton ringan yang telah terbentuk dikeringkan pada suhu ruangan selama 28 hari sebelum digunakan untuk pengujian sesuai standar.

\subsection{Pengujian Daya Serap Air}

Papan beton ringan ditimbang untuk menentukan massa kering $\left(m_{k}\right)$, kemudian papan direndam dalam air selama 24 jam dan diukur massa nya sebagai massa basah $\left(m_{b}\right)$. Nilai daya serap air papan beton ringan dapat dihitung berdasarkan Persamaan 1.

$$
D S A=\frac{m_{b}-m_{k}}{m_{k}} \cdot 100 \%
$$

dengan $m_{k}$ adalah massa sampel uji kondisi kering (g) dan $m_{b}$ adalah massa sampel uji kondisi basah setelah direndam air $(\mathrm{g})$.

\subsection{Pengujian Densitas}

Papan beton ringan yang bermassa kering $\left(m_{k}\right)$ ditimbang dengan menggunakan timbangan digital, kemudian diukur besar volume pada papan beton. Nilai densitas papan beton ringan dapat diketahui dengan cara membagi massa per volume yang berdasarkan Persamaan 2.

$$
\rho=\frac{m}{V}=\frac{m_{k}}{p l t}
$$


dengan $\rho$ adalah densitas $\left(\mathrm{g} / \mathrm{cm}^{3}\right), m_{k}$ adalah massa sampel uji kondisi kering $(\mathrm{g}), v$ adalah volume sampel uji $\left(\mathrm{cm}^{3}\right), p$ adalah panjang sampel uji $(\mathrm{cm}), l$ adalah lebar sampel uji $(\mathrm{cm}), t$ adalah tebal sampel uji $(\mathrm{cm})$.

\subsection{Pengujian Kuat Lentur}

Papan beton ringan yang telah dicetak diletakkan pada bagian UTM (Universal Testing Machine) untuk diuji kelenturan papan beton ringan. Kegunaan pengujian kuat lentur adalah untuk mengetahui kemampuan papan beton menahan gaya lentur yang diberikan dengan arah tegak lurus terhadap penampang. Saat papan beton ringan mengalami patah maka skala yang tertera akan terlihat untuk nilai kuat lentur pada UTM (Universal Testing Machine), kemudian dicatat sebagai nilai beban maksimum $\left(m_{p}\right)$. Selanjutnya nilai kuat lentur $\left(f_{r}\right)$ dapat dihitung dengan menggunakan Persamaan 3.

$$
f_{r}=\frac{3 m_{p} s}{2 l t^{2}}
$$

dengan $f_{r}$ adalah kuat lentur $\left(\mathrm{kgf} / \mathrm{cm}^{2}\right), m_{p}$ adalah beban patah maksimum $(\mathrm{kgf}), s$ adalah jarak tumpuan $(\mathrm{cm}), l$ adalah lebar sampel uji $(\mathrm{cm})$ dan $t$ adalah tebal sampel uji $(\mathrm{cm})$.

\subsection{Pengujian Kuat Tekan}

Pengujian kuat tekan dilakukan dengan menggunakan UTM (Universal Testing Machine) uji kuat tekan untuk mengetahui kuat tekan hancur sampel uji. Pengujian dilakukan dengan cara meletakkan sampel uji pada bagian mesin tempat meletakkan sampel uji. Kemudian diberikan pembebanan diatas sampel uji tersebut. Skala yang tertera pada mesin uji saat benda uji mengalami retakkan dicatat sebagai hasil beban maksimum $(P)$. Selanjutnya nilai kuat tekan $\left(f_{c}\right)$ dapat dihitung dengan menggunakan Persamaan 4.

$$
f_{c}=\frac{P}{A}
$$

dengan $f_{c}$ adalah kuat tekan $\left(\mathrm{kgf} / \mathrm{cm}^{2}\right), P$ adalah beban maksimum sampel uji (kgf), dan $A$ luas permukaan sampel uji $\left(\mathrm{cm}^{2}\right)$.

\section{HASIL DAN DISKUSI}

\subsection{Daya Serap Air}

Daya serap air memperlihatkan bagaimana kemampuan dari papan beton untuk menyerap air, dimana papan beton ringan yang diharapkan memiliki daya serap air kecil. Papan beton ringan berserat pinang dan foam agent memiliki nilai daya serap air rata-rata yang cukup tinggi. Nilai daya serap air terendah terdapat pada papan beton normal sebesar $13,86 \%$ seperti ditunjukkan Gambar 1. Jika dilihat dari papan beton yang memiliki serat dan foam agent, nilai daya serap air terendah dimiliki oleh papan beton dengan 0,8\% serat, yaitu $14,69 \%$. Penambahan serat pinang yang semakin banyak menyebabkan nilai daya serap air papan beton setelah perendaman selama 24 jam semakin kecil. Semakin tinggi densitas papan beton maka ikatan antar partikel semakin kompak sehingga rongga udara dalam lembaran papan mengecil. Keadaan ini menyebabkan air atau uap air menjadi sulit untuk mengisi rongga tersebut. Jika dibandingkan dengan nilai daya serap air papan GRC, yaitu 19,27\%, maka nilai daya serap air papan beton ringan serat pinang dan foam agent lebih kecil. Apabila dibandingkan dengan SNI 03-2105-2006 yang menetapkan nilai daya serap air maksimal 14\%, maka nilai daya serap air papan beton ringan serat pinang dan foam agent belum sesuai. 


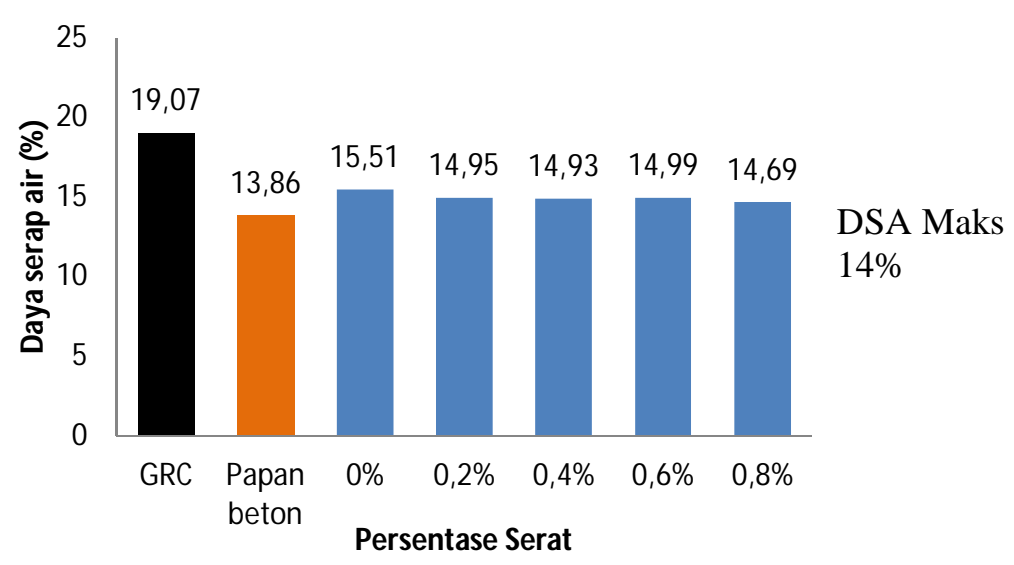

Gambar 1 Grafik pengaruh persentase serat sabut pinang dan foam agent terhadap daya serap air.

\subsection{Densitas}

Pada Gambar 2 dapat dilihat bahwa nilai densitas tertinggi dimiliki oleh papan beton normal yaitu sebesar $1,62 \mathrm{~g} / \mathrm{cm}^{3}$. Kemudian nilai densitas terendah pada $0,6 \%$ serat, yaitu 1,42 $\mathrm{g} / \mathrm{cm}^{3}$. Nilai densitas yang rendah disebabkan oleh serat yang terdapat pada pasta beton sehingga terbentuk rongga udara pada papan beton. Selain itu, foam agent juga menyebabkan terbentuknya gelembung-gelembung udara pada proses pengadukan yang mengakibatkan munculnya rongga di dalam beton pada saat mengering sehingga membuat berat jenis beton menjadi kecil (Simbolon, 2015). Nilai densitas berbanding terbalik dengan nilai daya serap air, semakin kecil densitas maka daya serap air akan semakin besar. Pernyataan tersebut memperkuat hasil pengujian, dimana semakin tinggi persentase serat, densitas papan semakin kecil, sedangkan daya serap air papan semakin besar (Sylvia, 2017). Pada penelitian ini nilai densitas yang diinginkan adalah nilai densitas terendah karena papan yang diharapkan adalah papan yang ringan namun kuat.

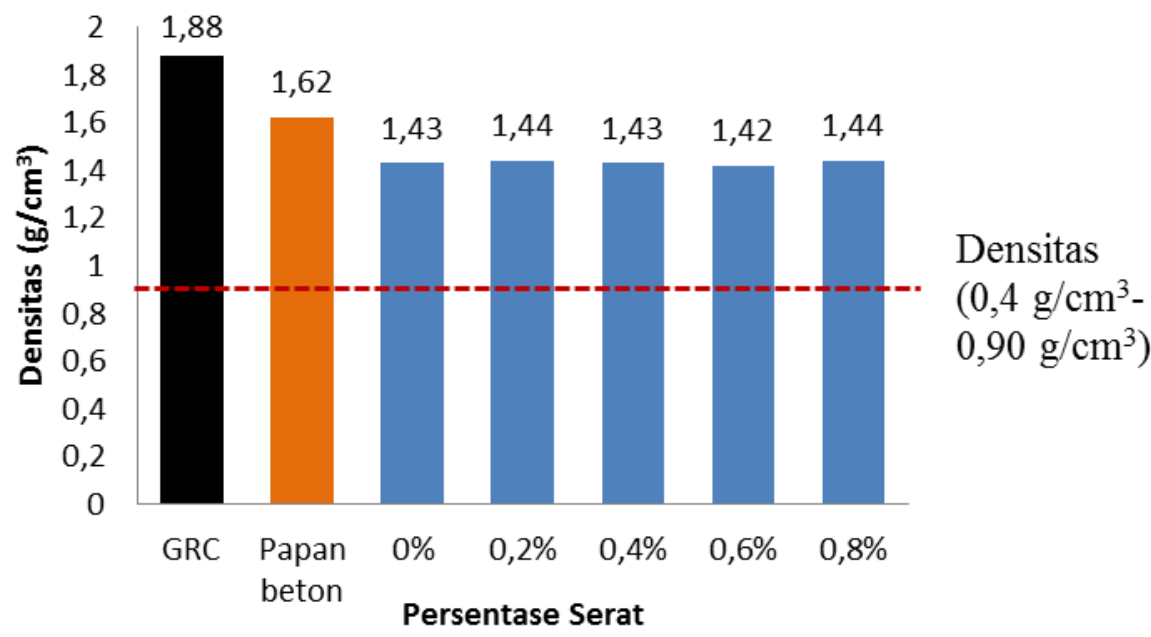

Gambar 2 Grafik pengaruh persentase serat sabut pinang dan foam agent nilai densitas.

Nilai densitas terendah terdapat pada $0,6 \%$ serat, yaitu sebesar $1,42 \mathrm{~g} / \mathrm{cm}^{3}$. Jika dibandingkan dengan nilai densitas papan GRC sebesar $1,87 \mathrm{~g} / \mathrm{cm}^{3}$, maka papan beton ringan berserat pinang dan foam agent jauh lebih rendah. Apabila dibandingkan dengan nilai densitas pada SNI 03-2105-2006 yang menetapkan sebesar $0,40 \mathrm{~g} / \mathrm{cm}^{3}-0,90 \mathrm{~g} / \mathrm{cm}^{3}$, maka nilai densitas beton berserat pinang dan foam agent belum sesuai karena nilai densitas SNI 03-2105-2006. 


\subsection{Kuat Lentur}

Berdasarkan hasil pengukuran dan perhitungan di dapatkan data seperti yang terlihat pada Gambar 3. Nilai kuat lentur tertinggi dimiliki oleh papan beton dengan $0,4 \%$ serat, yaitu $37,5 \mathrm{kgf} / \mathrm{cm}^{2}$, sedangkan nilai terendah pada $0 \%$ serat sebesar $25,5 \mathrm{kgf} / \mathrm{cm}^{2}$. Hal ini terjadi karena tidak adanya serat yang terkandung di dalam matriks yang berfungsi untuk menahan beban yang diberikan sehingga papan beton menjadi mudah patah dan nilai kuat lentur yang dihasilkan menjadi kecil. Jika di bandingkan dengan papan GRC yang memiliki nilai kuat lentur $112,5 \mathrm{kgf} / \mathrm{cm}^{2}$, maka nilai kuat lentur papan beton berserat pinang dan foam agent lebih rendah. Nilai kuat lentur tertinggi papan beton berserat pinang dan foam agent diperoleh pada $0,4 \%$ serat sebesar $37,5 \mathrm{kgf} / \mathrm{cm}^{2}$.

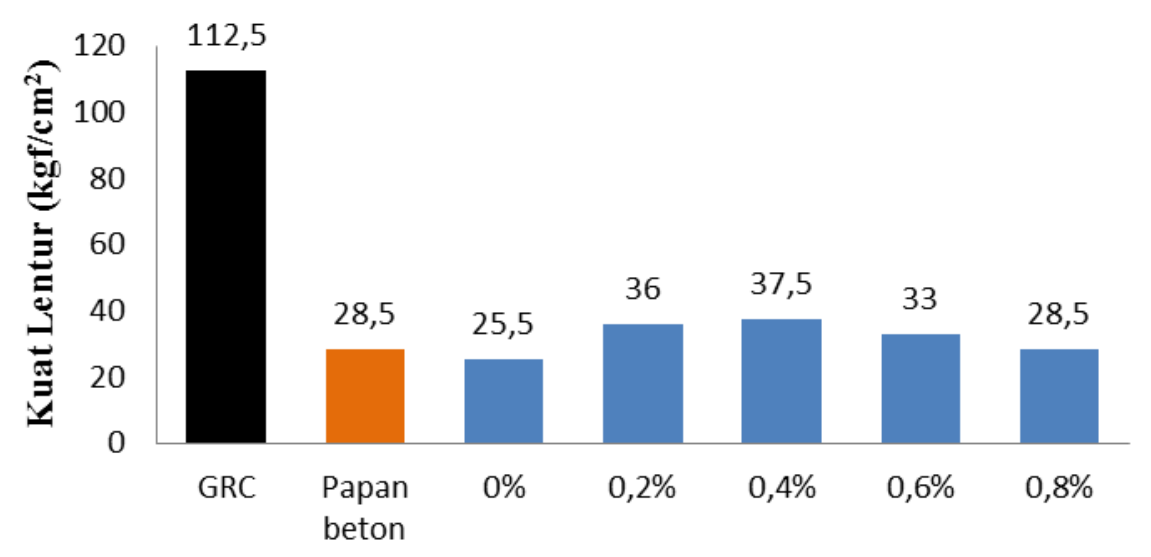

Persentase Serat

Gambar 3 Grafik pengaruh persentase serat sabut pinang dan foam agent terhadap kuat lentur.

\subsection{Kuat Tekan}

Hasil yang didapat berupa data seperti yang tertera pada Gambar 4. Nilai kuat tekan terendah papan beton serat pinang dan foam agent terdapat pada $0,4 \%$ serat sebesar 36,87 $\mathrm{kgf} / \mathrm{cm}^{2}$. Rendahnya nilai kuat tekan dipengaruhi oleh banyaknya rongga udara yang terdapat pada papan beton yang membuat papan beton tidak padat dan rapuh. Selanjutnya kuat tekan tertinggi diperoleh pada $0,2 \%$ serat sebesar $54,87 \mathrm{kgf} / \mathrm{cm}^{2}$. Penambahan serat pinang yang lebih banyak menyebabkan kuat tekan papan beton menurun (Olanda dan Alimin, 2013) Ini menunjukkan jumlah maksimum yang dapat diisikan sebagai penguat pada matriks. Jumlah serat yang melebihi batas maksimum akan membuat papan semakin rapuh, karena semakin memperlemah ikatan antar matriks.

Jika dibandingkan dengan nilai kuat tekan papan GRC, yaitu 94,27 kgf $/ \mathrm{cm}^{2}$, maka papan beton ringan berserat pinang dan foam agent memiliki nilai kuat tekan yang lebih rendah. Nilai kuat lentur tertinggi papan beton serat pinang dan foam agent didapatkan pada 0,2\% serat, yaitu $54,87 \mathrm{kgf} / \mathrm{cm}^{2}$. Berdasarkan SNI 03-3449-2002, papan beton serat pinang dan foam agent merupakan konstruksi bangunan struktural sangat ringan sebagai isolasi. 


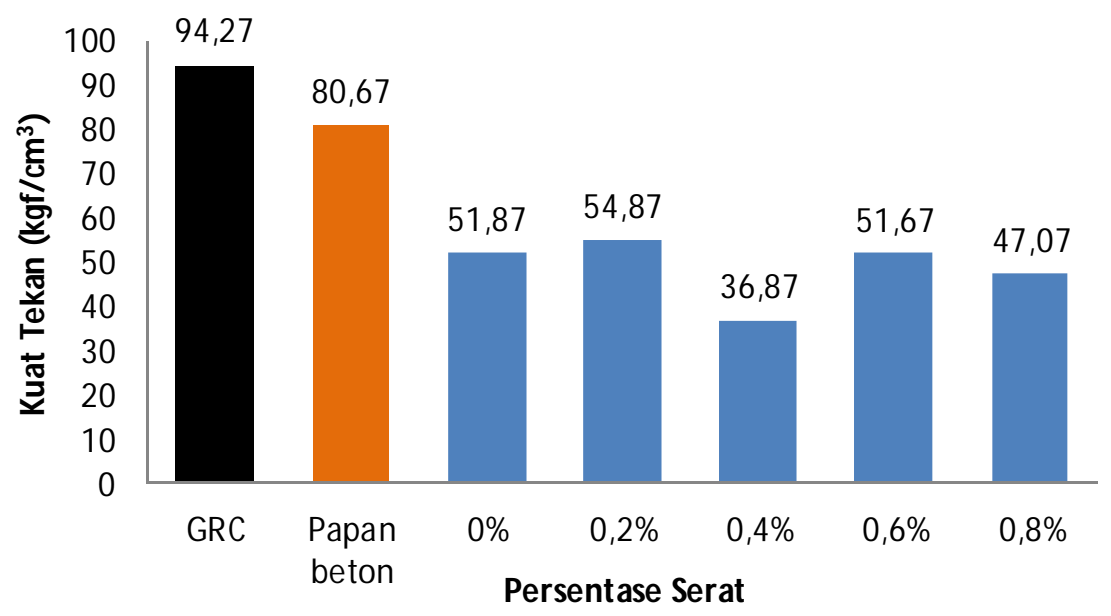

Gambar 4 Grafik pengaruh persentase serat sabut pinang dan foam agent terhadap kuat tekan.

\section{KESIMPULAN}

Penambahan serat pinang dan foam agent berpengaruh terhadap sifat fisik dan mekanik papan beton. Kuat lentur optimum diperoleh pada persentase $0,4 \%$ serat sebesar $37,5 \mathrm{kgf} / \mathrm{cm}^{2}$. Selanjutnya papan beton serat pinang dan foam agent yang memiliki nilai daya serap air terendah diperoleh pada $0,8 \%$ serat sebesar $14,69 \%$, sedangkan nilai densitas terendah terdapat pada $0,6 \%$, yaitu $1,42 \mathrm{~g} / \mathrm{cm}^{3}$ dan nilai ini lebih baik dibandingkan nilai papan GRC.

\section{DAFTAR PUSTAKA}

Gargulak, J. D., Bushar, L. L., Sengupta, A. K., 2001, Ammoxidized Lignosulfonate Cement Dispersant, US-Paten : US 6,238,475 BI.

Murtono, A., 2015, "Pemanfaatan Foam Agent dan Material Lokal dalam Pembuatan Bata Ringan", Naskah Publikasi, Jurusan Teknik Sipil, Universitas Muhammadiyah Surakarta.

Nurrahkman, A., Triwulan., Januarti, J, E., 2014, "Serat dan Foaming Agent pada Campuran Beton Ringan Berbahan Dasar Lumpur Sidoarjo dan Abu Sekam”, Jurnal Teknik Pomits, Vol. 1, No. 1, Jurusan Teknik Sipil, ITS.

Olanda dan Alimin, 2013, "Pengaruh Penambahan Serat Pinang (Areca Catechu L. Fiber) terhadap Sifat Mekanik dan Sifat Fisis Bahan Campuran Semen Gipsum", Jurnal Fisika Unand, Vol.2, No.2, Jurusan Fisika Unand.

Sylvia, Y., 2017, "Pengaruh Persentase Serat Sabut Pinang (Areca Catechu L. Fiber) terhadap Sifat Mekanik dan Fisik Papan Gipsum-Beton", Skripsi, Jurusan Fisika, Universitas Andalas.

Tjokrodimuljo, K.., 1996, Teknologi Beton, Nafiri, Yogyakarta. 